\title{
Reflective sessions: a tool for teacher empowerment
}

Maria Cecília Camargo Magalhães

Maria Antonieta Celani

PUC-SP

O objetivo deste artigo é discutir até que ponto sessões reflexivas podem tornar-se uma ferramenta para o empoderamento do professor quando incluída em um curso de formação contínua reflexiva, e entendida como uma atividade de sala de aula que oferece a possibilidade de construção de um novo tipo de organização discursiva.

A discussão será feita, por um lado, focalizando a necessidade de se oferecer às professoras de inglês da escola pública brasileira engajadas em um programa de educação contínua um contexto que leve à prática reflexiva, e, por outro lado, focalizando a efetividade de se organizar esse contexto na forma de discussão em duplas, a fim de se criar um espaço colaborativo para as professoras examinarem suas aulas criticamente. Pretende-se que as participantes aprendam a avaliar sua prática de sala de aula, encarando esse espaço como um locus de investigação e de (des)construção de teorias. O artigo discute o processo educacional resultante das discussões, analisando os discursos das duplas (BRONCKART, 1999), isto é, as escolhas lingüísticas discursivas que revelam seus motivos quando interagindo com um par a fim de avaliar suas práticas criticamente. Isso também trará alguma indicação a respeito do nível de efetividade da própria ferramenta.

The aim of this paper is to discuss to what extent reflective sessions can become a tool for teacher empowerment when included as a component of a reflective teacher education in-service course, and understood as a classroom activity which provides the possibility for a new type of discursive organisation to emerge. The discussion will be of a twofold nature: on the one hand it will focus on the need to provide Brazilian state school teachers of English involved in a continuing education programme with a context conducive to reflective practice and, on the other hand, it will focus on the effectiveness of organizing that context as discussion dyads, so as to create a collaborative set up for participants to examine their classes critically. The aim set for the participants is learning how to evaluate each other's classroom practice by looking at it as a locus of investigation and of theory (de)construction. The paper discusses the educational process evolving from the discussions by analysing the dyads' discourses (BRONCKART, 1999), i.e., the linguistic discursive choices that reveal their motives when acting with a pair in order to evaluate their classroom practices critically. This will also shed some light on the level of effectiveness of the tool itself. 


\section{Introduction}

This paper is set within the context of a wide teacher education project which aims at enabling teachers to become multipliers in their own schools. One of the issues that the project is concerned with is understanding how public school English teachers, as professionals, can be educated to become reflective and critical within the boundaries of a course structure. The aim of this paper, however, is to discuss to what extent reflective sessions, included as a component of a reflective teacher education in-service course, and understood as a classroom activity which provides the possibility for a new type of discursive organisation to emerge can become a tool for teacher empowerment.

The discussion will be of a twofold nature: on the one hand, it will focus on the need to provide Brazilian state school teachers of English involved in a continuing education programme with a context conducive to reflective practice and, on the other hand, it will focus on the effectiveness of organizing that context as discussion dyads, so as to create a collaborative set up for participants to examine their classes critically. The aim set for the participants is learning how to evaluate each other's classroom practice by looking at it as a locus of investigation and of theory (de)construction. The paper discusses the educational process evolving from the discussions by analyzing the dyads' discourses (BRONCKART, 1999), and also the linguistic discursive choices that reveal their motives when acting with a peer in order to evaluate their classroom practices critically, based mainly on Smyth's (1992) analytical framework. This will also shed some light on the level of effectiveness of the tool itself.

This paper is organised into five sections: firstly, the general research context is presented; secondly, its theoretical background is described; thirdly, the more specific context concerning the data collection is presented; fourthly, the results are presented and discussed and, finally, the results and possible implications for course restructuring are commented on.

\section{The structure of the research context}

The research context is a reflective teaching programme involving three institutions: a large non-profit language teaching organisation (Associação de Cultura Inglesa - São Paulo), a university (Catholic 
University of São Paulo), and the state of São Paulo public school system, where the teachers participating in the project work. The Cultura Inglesa sponsors the whole programme and offers language improvement (one to three years, depending on teachers' needs) and the Catholic University is responsible for the one-year reflective course - Reflection on and in action: the English teacher learning and teaching. The course was offered for the first time in 1997 and, at the moment data were collected, the whole programme in its various stages involved about 1400 state school teachers.

The research site was the course taught at the Catholic University of São Paulo by a team of teachers and researchers from the Graduate Programme in Applied Linguistics and from the English Department, in 2000. It was a 150 hour course comprising eight modules and taught in two semesters. ${ }^{1}$ At the end of the course the teachers get involved in becoming multipliers by means of monthly workshops offered to the whole English teaching community in the state of São Paulo.

In order to make clear where the research is set, it is necessary to describe the course structure, the participants and how they connect with the workshops. The course consists of eight interrelated modules, four concerned with the development of reflective learning and four concerned with classroom matters and syllabus design. The former include topics such as (a) learning to learn: the importance of reflection; (b) reflecting on the reconstruction of theory from practice; (c) self-evaluation as a reflective process; (d) the role of the multiplier in the reflective process. The latter include topics such as (a) reflecting on the needs of the public school student: which skills to prioritise; (b) reflecting on the social practice of discourse; (c) rethinking English phonology: from awareness to action and (d) reflecting on English grammar. All the modules are closely interrelated, in the sense that those more concerned with developing a reflective posture serve as basis for those more concerned with factual classroom aspects.

The participants in the research project were state school teachers, i.e., teachers taking the course (henceforth referred to as teacher-students); course teachers, i.e., those teaching the modules, and researchers, i.e., people involved in doing research connected with the project, but not teaching in the course. The authors of this paper are part of the research group.

${ }^{1}$ The course has become now a 228 three semester course. 
The focal participants consisted of 20 state school English teachers, all graduates holding a teaching certification. Despite having obtained tenure through a public examination on a competitive basis, they all felt that they still needed a language improvement course offered by the institution sponsoring the programme. Depending on individual needs, the language improvement course may last for between one to three years, and at the time that the data were collected there was a compulsory requirement for starting the reflective course at the university. Very few participants had taken regular extension courses, but a fair number had sometimes attended workshops, usually offered by publishers. Their teaching experience ranged from 4 months to 24 years, about one third concentrating on the 5 to 10 year range. All had very heavy teaching loads, a minimum of 20 contact teaching hours weekly to a maximum of 40 , often in three shifts in different schools. All taught very large classes (about 40 students minimum), in schools with very limited resources in difficult urban areas with violence and poverty spreading over. Both students and teachers, with very few exceptions, came from a low socio-economic background.

Brazilian state school teachers in the late 90's reflect the educational picture of the country in terms of lack of preparation deriving from the type of pre-service courses offered in most universities, the different type of student that they have to deal with, the change in institutional support, etc. These teachers, although coming from different pre-service teacher education institutions, where they obtained their first degree, share the ELT culture prevailing in the vast majority of these institutions. Their adoption of methodologies will be influenced by factors generated by that culture: a culture of prescription of techniques with no reflection. Teachers' histories and the ways they were taught will certainly influence their thinking and representations regarding teaching English in a state school. They will be influencing their reflective teaching process as well (AU, 1990; FULLAN, 1996).

The specific research context for this paper is a reflective session in a class, part of the module The role of the multiplier in the reflective process taught at the end of the course. 


\section{Theoretical background}

This study is supported by four main theoretical bases: (1) the socio-cultural (VYGOTSKIAN) studies perspective, which emphasises social factors as well as language and education as crucial tools in actively directed learning, in development, and in the process of consciousness; (2) the Bakhtinian focus on dialogism; (3) discourse organization and analysis as key concepts in the process of critical reflection and (4) the crucial role of critical reflection in teacher continuing education.

\section{Socio-cultural research and continuing teacher education}

Although Vygotsky's sociocultural approach to mind has been mainly directed to child learning and development, in this paper we will extend it to the discussion of teachers' theory construction, as already done by $\mathrm{Au}$ (1990). In this paper, we are interested in the teachers' restructuring of their representations of the concepts of English as a foreign language teaching-learning, as well as of their roles as teachers.

Three concepts are important in this discussion: (1) the social condition of learning and the crucial role of others in learning and development through language mediation; (2) the processes of internalisation and externalization; and (3) the dialectic relationship between scientific and spontaneous concepts. All of them are indivisibly interrelated in teachers' consciousness of their classroom language actions. In fact, a teacher's collaborative action with a peer or a researcher (MAGALHÃES, 1999) has been found to be a powerful tool for restructuring and reculturing, since the negotiation provides a context for critical reflection on his/her tacit, spontaneous knowledge as related to scientific ways to understand it. As already discussed by Au (1990, p. 272), based on Vygotsky (1978, 1987), the dialectic relationships between scientific and spontaneous concepts, ${ }^{2}$ in teachers' concept construction processes, can provide deeper understanding of the relationships between theory and practice in a particular domain.

\footnotetext{
${ }^{2}$ Vygotsky's discussion of child development proposes a dialectic interaction between everyday or spontaneous concepts and scientific concepts. Spontaneous concepts are those which are formed by children in the processes of living, while the scientific ones are formed at school through instruction and directed toward consciousness and deliberate use.
} 
This paper considers that the teachers' growing consciousness processes are related to their understandings and misunderstandings and that they are dependent on social interactions which provide teachers with a context to describe, to make their concept comprehension explicit and open it up for evaluation. Since this collaborative process promotes the possibility of restructuring, in this paper, a discussion in dyadic form of the participating teachers' own classes is the context provided. Based on the Vygotskian framework, the term collaborative is understood here as the kind of interaction in which meanings are constructed by all participants. As discussed by Wertsch and Smolka (1993), these are interactions in which a participant takes the utterance of the other as a thinking strategy (WERTSCH and SMOLKA, 1993).

\section{Dialogism and continuing teacher education}

As discussed by Holquist (1990), a dialogic concept of language is fundamental in Bakhtin's work, which stresses dialogism as context, as a place for constant battle between meanings by the participants of discourse. In this paper dialogism is understood as "the kind of relation conversations manifest, the conditions that must be met if any exchange between different speakers is to occur at all" (HOLQUIST, 1990, p. 40).

In this respect, as pointed out by Crowley (1990, p. 69-70), dialogism is employed in late Bakhtinian work in at least three distinct ways: (1) to refer to "the historical forces which are in conflict in discourse: dialogical versus monological forces"; (2) to refer "to the effects brought about by the conflict: monological or dialogical forms of discourse" and (3) to refer "to the nature of the conflict itself" and to the constant renegotiations between agents to maintain the position conquered."

The complementarity between Vygotsky and Bakhtin, as pointed out above, in relation to the way of looking at language as a semiotic tool and the polyphonic characteristic of meaning construction in discourse, will allow us to understand the agent responsive reactions to other utterances in a particular sphere of communication. In other words, in this paper, dialogism will allow us to analyse semiotic mediation in a particular situation of communication - dyadic discourse - in order to understand if and how the teachers provided each other with the possibility of constructing new meaning by appropriating the voice of the other and by using it as a thinking strategy. 


\section{Discourse and critical reflection}

Schneuwly (1994) revisits the discussion of tool as found in Vygotsky's work and highlights its threefold characteristic: an agent, an object and a situation that is acted on. The intervention of tools, understood as socially organised object, assigns the activity a certain format; changes in the tools will imply a transformation of behaviours in a given situation. As pointed out by Schneuwly (1994, p. 157-158), tools become "the privileged space for transformation of behaviour: exploring their possibilities (the possible uses of tools), enriching and changing them are means of also changing the activity to which it is connected. Considering that language actions are, as stated by Schneuwly, "at least in part, pre-established by instruments, knowledge and perception of reality are partially built within the means of acting upon them."

In this study, the event reflective session aimed at providing teachers with a basis that would guide their discursive action. That is, the different levels of actions needed for production of texts: theme, discourse and language choices that may allow them to efficiently act when collaborating with a peer in trying to analyse their classroom practices.

Communicative action theory, as stated in Habermas (1981, 1990), offers an important theoretical framework that works in the direction of the discussions held by Vygotsky and Bakhtin due to its claim that subjects are shaped through assessment of their actions with the use of language. His concepts of world of life - that is behind us and, therefore, accessible only through interaction with an "other", and of represented worlds - objective, social and subjective worlds -, offer us an interesting framework to discuss knowledge construction during interaction. In the same direction as Vygotsky and Bakhtin, communicative action presupposes the creation of space for reflection and new sense and/or meaning construction.

\section{Reflection and continuing teacher education}

Researchers (e.g., FULLAN, 1996; PERRENOUD, 1999; CELANI, 2000; MAGALHÃES, 1994, 1996, 1999, among others) have pointed out the gap between the development of educational research and school transformation. As indicated by Fullan (1996, p. 421-422), teachers' continuing education projects with greater probability of success need to provide the possibility for reculturing. That is, the possibility for 
developing new representations about teaching-learning, about instruction, about dialogical interaction patterns, and about new forms of professionalism; in summary, new political and ideological representations of teachers' roles. Perrenoud (1999), discussing reculturing, stresses the fact that it is a basis for teachers restructuring, that is, acting based on these new cultural representations and by doing that being able to structure their actions differently: they will represent themselves as reflective professionals based on a critical practice.

As pointed out in the discussion above, ways to provide reculturing and restructuring are related to the creation of a zone of negotiation. This may provide teachers with the possibility of reflecting not only on their school practice and on their representations of culture that support their comprehension of school dialogues, but also on their comprehension of themselves as professionals in the particular context up which they act. Zeichner and Liston (1987) discussed several strategies (e.g. diaries, ethnographies, action research, reflective sessions) to help student teachers or teachers to organise discourse in ways that might provide them with the construction of a reflective practice concerning new construction of knowledge.

In this study this possibility is provided by the teachers dyads who discuss each other's classes. This discussion, here referred to as reflective session, was supposed to be a locus of collaborative investigation of the conflicting ways the participants evaluate and represent their own ways of acting, their intentions and motives to act and those of others, within a specific school context. It should make it possible for them to understand each participant's representations about teaching concepts, classroom discursive practice organisation, classroom discursive practice questioning and new forms of knowing, of acting and of negotiating.

In summary, the reflective session was thought to be a strategy to work with teachers, in the last module of the course, so as to give them a context in which they would relate the theories and practices discussed throughout the course modules, and develop a collaborative action with a peer to discuss the themes pointed out above. In other words, to learn to act as a multiplier. So, teachers would experience the complexity of the context they face and would learn how to structure their utterances in order to, by questioning the other's actions and making their own explicit, create a context for discussion with their peers. This session was followed by a discussion in which the course 
teacher focused on the ways teachers organised their utterances to question or to answer in order to really develop a reflective practice as professionals.

Reflection is understood as reorganisation or reconstruction of practices that may conduct to new understanding of the context of a specific practice which is seen as problematic by a participant of an interaction action (GRIMMETT, 1988 apud PÉREZ GÓMEZ, 1992, p.12). According to Grimmett, reflection is a means to practice understanding and transformation and involves (a) rethinking the situation by asking clarification questions; (b) discussing aspects that had previously been ignored; (c) attributing new meanings to situation already discussed. However, more than that, reflecting necessarily involves reculturing in order to, actually, reach restructuring.

Researchers, based on varied theoretical frame (e.g., WERTSCH and SMOLKA, 1993 - based on Vygotskian and Bakhtinian frames; COULTER, 1999 - based on Bakhtinian frames; SCHÖN, 1987, 1992 and SMYTH, 1992 - based on the Deweyian and Freirian discussion on reflection, among others), have proposed ways to examine interaction in order to analyse the kind of knowledge that is discussed, the roles of the participants, as well as the possibilities for knowledge construction. For instance, Schön (1987) proposes two patterns, which he called Model I and Model II, to analyse the interactional pattern of a negotiation between asymmetric dyads (i.e., teacher/researcher, or teacher/teacher when one member has the function of questioning, as in this paper). Restricted to the discussion of classroom culture, mainly to technical/cognitive themes of teaching-learning, Model I is based on values that emphasise achieving one's own objective with no negotiation of meaning, i.e., values such as: achieve the objective as $I$ (the more powerful member) see it, strive to win and avoid losing, avoid negative feelings and be rational to persuade others.

On the other hand, Model II, influenced by Rogerian bumanism, aims at creating a context in which people exchange valid information, even about difficult and sensitive matters, submit private dilemmas to shared inquiry, and make public tests of negative attributions that Model I keeps private. However, even Model II keeps reflection within the technical content of classroom culture, which might be problematic for reculturing to take place as well as for restructuring.

Ways of organising and analysing reflective interactions which provide the possibility of focussing the broader cultural political context 
have been put forth by Smyth (1992, p. 295), based on the work of Freire (1972). He proposes four ways that might provide teachers with a framework for organising their reflective actions. These ways of acting are related to different ways of self-questioning:

$\begin{array}{ll}\text { Describing } & - \text { What do I do? } \\ \text { Informing } & - \text { What does it mean? } \\ \text { Confronting } & - \text { How do I come to be like that? } \\ \text { Reconstructing } & \text { - How could I act differently? }\end{array}$

These actions would allow the agents to reflect upon their classroom language actions while interacting with another participant, and because of the other's questioning to be capable to describe them in a critical way. This creates the possibility for the teacher to clarify former representations as well as to establish a relationship between intention and action. By organising their discourse around utterances that create a space for critical thinking, it will be possible for both teachers in a dyad to confront their representations concerning themselves as professionals (what it means to be a teacher in that specific context, what kind of student they are educating), as well as to confront the real interests that inform their actions (are they working to maintain or transform the institutional context, discourses, and values they are questioning). In fact, in order to question meaning, it is necessary to establish a problem.

Therefore, as also discussed by Liberali (1999) by engaging in these four forms of actions related to their teaching, teachers will focus on those aspects that, for some reason, are a problem for them, or that were questioned by other participants. Also, by addressing the problem with other participants' collaboration it may be easier for them to deal with conflicting meanings, to reflect on them, to uncover how they come to act that way, and to reconstruct theory and practice. So, these actions would make it possible for agents to reflect on and to question their classroom actions, as well as their representation of the interests they are working for.

\section{The reflective sessions}

The context for this study was, as already mentioned, a class in the last module of the course which had the objective of providing teachers with instruments enabling them to understand classroom 
practice as a locus of investigation and of theory (de)construction. The class was organised into dyads. According to the task organisation, each member of the dyad gave the other a transcript of a class previously recorded on video for discussion. Also each member of the dyad was supposed to prepare beforehand the issues to be focused on during the discussion session based on Smyth's frame already discussed by the class teacher. During that module teachers had discussed theories on reflection, types of reflection, reflection procedures, how to interact with a colleague. Apart from the reflective sessions, teachers also had written diaries, life histories as part of the course.

Sometimes the class teacher interfered in the dyads' discussion by modelling for the benefit of the participants in the reflective session how to organise their discourse to interact with a colleague in order for reflective practice to really take place. Although both classes in each dyad were discussed, only one class of each dyad was recorded for the purpose of this study.

The twelve participant teachers were divided into 5 dyads:

- dyad 1: Ana (A) and Beth ${ }^{3}$ (B) discussing Beth's class;

- dyad 2: Claudia (C) and Dora (D) discussing Claudia's class;

- dyad 3: Fernanda (F) and Gina (G) discussing Gina's class;

- dyad 4: Jill (J) and Kate (K) discussing Jill's class;

- dyad 5: Nina (N) and Olga (O) discussing Nina's class.

Since it was the purpose of the course to prepare teachers to be multipliers in their schools, in examining the data we looked for indications of how teachers interacted during the discussion and to what extent they really reflected or promoted reflection on their own and on their peer's teaching practices in ways that revealed whether reculturing and restructuring were taking place. Reflection was understood based on the actions proposed by Smyth (1992) so we were able to realize how teachers had appropriated the classroom discussion. This paper discusses the educational process evolving from the discussions by analyzing the dyads' discourses (BRONCKART, 1999), i.e., the linguistic discursive choices that reveal their motives when acting with a peer in order to evaluate their classrooms practices critically. This will also shed some light on the level of effectiveness of the tool itself.

\footnotetext{
${ }^{3}$ All names are fictitious.
} 


\section{Description and discussion of results}

We could say that the event reflective session provided teachers with a context to organize their discourse in ways that are not usually valued in school settings. This new organization derived from the need for the creation of contexts that would allow for the education of a reflective teacher with critical practice. The discussion of action that comprises reflection of educational practices, as pointed out by Smyth (describing, informing, confronting and reconstructing), was used as a basis, as an instrument to allow teachers being educated to become multipliers in their own schools. That is, to relate tacit knowledge acquired with their classroom practices as students and/or teachers to formal (theoretical) knowledge (e.g.: theories of teaching-learning, of development, of language). The aim was thus to educate critical professionals who could reflect upon their practices and upon the education of their students.

Since this paper discusses a moment in one module during which the teacher works with this tool for the education of multiplier-teachers, our purpose is to examine how teachers internalised and externalized this tool, the type of reflection proposed and how the 5 dyads studied organised their discourse so as to meet the objective put forth by the teacher of the module: discuss a lesson taught by one of them, based on the actions suggested by Smyth (1992), in order to provide a context for critical reflection that would allow for tacit concepts (not yet reflected upon) connected with classroom practice to be linked to scientific concepts discussed during the course, thus allowing for actions from classroom practice to be reconstructed.

For the analysis we will initially examine the general plan of the session, i.e., how the dyads organised their discourse. We will then analyse how each action was organised within the discourse. Finally, we will discuss how the tool allowed for the construction of the reflective process to occur.

\section{The general discursive organisation of the sessions}

The description of the 5 dyads analysed reveals that the reflective sessions were fundamentally organised, in respect to the type of predominant discourse, as what Bronckart (1999) defines as interactive discourse, as expected, since the two teachers in each dyad established 
a direct dialogue, in a common time-space. Thus, we find an exposition in dialogue form, whose discursive markers reveal that the discursive world is, on the one hand, conjoined, as although mobilising a well delimited thematic content, its formal coordinates are presented as conjoined to the ordinary world of the interaction. This can be seen in the temporal system used, in which the present and the perfect tenses are predominant (BRONCKART, 1999, p. 158). On the other hand, that world is also implied, in the sense that explicit references are made in the text to the physical parameters of the language being used. For example, the units of the text segments in several instances refer directly to the agents of the interaction - I, you $(e u, v o c \hat{e}, t u)$, as revealed in the example below:

A40: Abm yes, yes, have I burt you by a question, or something? ${ }^{4}$

B38: Don't be silly (you).

However, the complexity of the production situation, in which the objectives to be reached at each moment of the interaction changed as a result of the previous turn, caused the representations mobilised in the text to be located in a time-space in disjunction in relation to the time-space of the previous enunciation, but still implying the physical parameters of the action of language. The result of that was a type of discourse of interactive report in which the teacher reports on her classes with the description and evaluation of the actions taking place in it. For example:

B1: [Looks upwards, seems to blink] How did I start [pause] Well, I thought that the class started to become good, that is ab... to be ok, when they began to understand and there was that interaction. When I asked and they answered. [A2: Sure. Nodding] there was a moment when everybody began to get excited, right? From the middle towards the end, right? Then I began to introduce the lesson, to talk, to remind them of some things and then there was a moment when they got it [snapping her fingers as a sign of victory].

In relation to the sequential organisation, each one of the reflective sessions was organised, globally, as a dialogic sequence, i.e., with an initial opening phase, a transactional phase in which the thematic content was

${ }^{4}$ All the excerpts were translated by the authors from the original in Portuguese. 
actually co-constructed and ended with a closing phase. The opening and the closing phases have phatic characteristics. Although the opening phase was rarely recorded in any of the dyads, the closing one was. For example, a segment of the dialogue between A and B:

A40: Abm yes, yes, have I burt you by a question, or something?

B38: Don't be silly (you).

A41: Thanks [laughing].

And this segment of the dialogue between $\mathrm{O}$ e $\mathrm{N}$ :

O25: hum

N24: Happy?

O26: [laughs].

Inside this global dialogical sequence, however, we find fragments of sequences describing actions, explaining and arguing. By looking at the teachers' choice in each one of these types of discursive organisation, we can understand the type of knowledge being constructed and how each member in the dyad played her role as instigator/provider of reflection and/or was able of reflecting on the teaching-learning contexts actually created, as well as on the type of reflection reached.

In this way, the transactional phase of the global dialogical sequence, in all dyads, was organised based on the theory discussed in the course: the actions proposed by Smyth to provide contexts in which actually the reflexive process would take place. Thus, in this phase, although following a structure with various types of prototypical sequences, the thematic content was organised first with a request for describing, moving on to requests for informing, confronting and ending with requests for reesructuring, followed or not by a final evaluation by the teacher in charge of bringing out reflection. That is, by "the other" as far as the teacher whose class was under discussion was concerned. For example, in dyad A and B, A, in charge of conducting the session, tried to lead $\mathrm{B}$ to describe her class for 7 turns, but gave up in the $8^{\text {th }}$ turn with a request for an explanation (informing):

A1: How did you start your class? Well, how did you decide to start your class?

B1: How I started...well, I thought the class started to become good, well ab! it started to become nice, when the students started to understand 
and there was that interaction. When I asked, they answered. [A2: $O K J$ At a certain point they started to get excited, from the middle to the end of the class. Then I started to introduce the lesson, to talk, to remind them of some things and then all of a sudden they got it ...

A3: How, then, did you feel you introduced this subject to them?

B2: How did I feel?

A4: No, how do you feel that you have introduced?

B3: Yes, if it was a success, is that what you mean? If it was OK?

A5: No, not exactly that. You said that they started participating from the middle of the class onward, right?

B4: Hum, bum...

A6: Well, bow do you think you started presenting?

B5: What was the whole class like?

A7: No, it isn't that. How do you think you went on presenting the lesson, how did you start talking, and they participating, was it right from the beginning?

B6: Well, I think a class has to have a beginning, this beginning a little bit listless

A:8: What were your objectives you had for that class?

A look at the sequencial organisations chosen for the organisation of the thematic content will show the way in which the different dyads appropriated the instrument - reflective session - and the concepts referring to each one of the actions of describing, informing, confronting and restructuring, as discussed by the teacher in the module under discussion. Also, by doing that, the risk involved in a context in which each member of the dyad made one of her classes the object of discussion will be made explicit. This issue was examined by Magalhães and Celani (2000) when discussing these data. They indicated how the risk involved in such a context seems to have influenced dyad A and B to structure the action of language as the genre interview. In other words, A structured her questions following a script, which followed the actions of describing, informing, confronting and restruscturing in a linear fashion. According to the authors, A seems to have been motivated by the evident discomfort of $\mathrm{B}$ in having her class questioned. This is apparent in her constant justifications (cf. Table 1) for the validity and efectiveness 
of her actions based on the chosen technique: chant, or on the students difficulties. What we have here is B interpreting A's question as a polemic question, under which there would be a positive thesis, i.e., "Is there another posture for this class?" When answering with a negative utterance B insists on the opposite thesis: "There's no other posture", offering the "chant" argument to confirm it. As an example let us look at the excerpt below:

A24: So do you think that there would be another way to act, something that could avoid pure imitation... this repetition that we've been talking about . do you think that there.would be any other way to use this same chant in some other way?

$\mathrm{B} 22:$ No, because the objective of using chant is repetition.

A25: $O K$.

B23: This is a technique, it is a method that was developed for that.

A26: OK [nodds].

B24: In order to repeat, it's repetition. This the method, it is used to repeat what came before [gestures with her hands].

A27: $O K$.

$\mathrm{B} 25:$ It is a little bit against what we saw, isn't it?

A28: Abmm.

B26: But, as I told you, my classes are not all like this one ... It was this one that I chose ... [moves her hands].

Table 1 gives a picture of the actions in the dyads A and B's interactions:

Table 1: Actions of dyads A and B

\begin{tabular}{|c|c|c|c|c|c|c|c|}
\hline Dyad 1: & $\begin{array}{c}\text { Request } \\
\text { for } \\
\text { describing }\end{array}$ & $\begin{array}{c}\text { Request } \\
\text { for } \\
\text { informing }\end{array}$ & $\begin{array}{c}\text { Request } \\
\text { for } \\
\text { confronting }\end{array}$ & $\begin{array}{c}\text { Request } \\
\text { for } \\
\text { Restructuring }\end{array}$ & $\begin{array}{c}\text { Requests/ } \\
\text { answers }\end{array}$ & Evaluation & $\begin{array}{c}\text { Total } \\
\text { number } \\
\text { of turns }\end{array}$ \\
\hline A & 7 & 9 & 6 & 6 & Reestruturing & 2 & 41 \\
\hline Justification & & 1 & & & & & \\
\hline & Describing & Informing & Confronting & Reestruturing & & & \\
\hline B & 2 & 8 & 1 & 1 & & & 38 \\
\hline Justification & & 12 & & & & & \\
\hline
\end{tabular}

A - Teacher conducting the reflective session

B - Teacher whose class was being discussed 
Let us now discuss the sequential organisations and their relation with the type of reflection reached.

\section{Sequential organisation and critical reflection}

In this section, we discuss the sequential organisation in the interactions in relation to the actions proposed by Smyth as providers of critical reflection with the objective of investigating how the teachers organised their discourse on the class under examination. To what extent, whithin the restrictions of a classroom activity, were they able, as discussed by Vygotsky and by Au, to relate spontaneous concepts (or non reflected formal theories) they had learned during practical experiences and the scientific concepts which had been the subject of the course in the construction of critical knowledge about teachinglearning, in their teaching practices.

The actions which we have characterised as describing were supposed to be structured as descriptions of concrete actions in the classroom, which made it possible or not for the teachers to look at their practice from a distance, a recovering of the objectives which were at the base of their actions and a new understanding in the light of formal concepts. But, there were moments in which the request for describing was answered with a description not related to any type of action. The excerpt below, a fragment of the interaction between $\mathrm{K}$ and $\mathrm{J}$, was almost entirely organised in a kind of descriptive form, which, as discussed by Smyth, does not provide contexts for critical reflection and consequently for possible reformulations, as there was no clear description of the actions performed. For example:

Fragment of a descriptive sequence of actions:

(a) anchorage phase, in which the theme of the description is signalled: "the class was about languages."

(b) descriptions of an action phase, in which the actions performed by the teacher are described:

"I gave the students a text about languages, the languages of the world, but before giving them this text I asked some questions in English and they were all put on the board. The students answered these questions $\mathrm{hm}, \mathrm{hm}, \mathrm{hm}$ according to their views, I was registering the answers of some five or six students [moves her hands] I considered the answers on the board but I 
didn't correct them depending on whether it was right or wrong according to the text, right? And after answering the questions..."

There were, however, interactions in which the actions of informing revealed moments in which the teachers, as a result of the description, started to analyse their own practices. Their statements reveal the theories in use, which still persist, based on spontaneous concepts or initial understanding of scientific concepts discussed in the course, but still understood in a mechanicist form, as the excerpts to be discussed will show.

Those statements appear, in general, as an answer to an initial request from the teacher conducting the reflective session, except in dyad 1 , and were organised as segments of sequences describing actions, mixed with fragments of explanatory sequences and/or argumentative ones (in rare cases), related to the action of informing, as discussed by Smyth (1992). Let us see some examples that illustrate these types of content organisation.

Teacher $\mathrm{C}$, when answering a request for description by $\mathrm{D}$, organises her answer with fragments of descriptive actions and of an argumentative sequence, justified by a report on the action of students questioning her action.

Example 1: Fragment of a descriptive action

The objective of $\mathrm{C}$ is to describe how she dealt with the genre letter in her class:

(a) anchorage phase, in which the theme of the description is signalled:

"Well, the class, the comment I made in relation to my class was that it dealt with a letter."

(b) description of action phase:

"yes, I put a model on the board, it was a formal letter, and after having said that I'd carry on with the class about formal letters and other possibilities, I just laid out the model for the letter."

Example 2: Fragment of an explanatory sequence

C's objective is made explicit as she sees her class as behavioristic - informing category. She justifies her need to give the students a model for the task (which lead her to describe her class as behavioristic) by saying that she was satisfying their needs.

(a) initial account, in which $\mathrm{C}$ introduces the students problematisation: 
"so, the girls (the peers) commented on because I took a ready made model for the letter with just a few possibilities for change, right?"

(b) problematisation, in which $\mathrm{C}$ questions herself why she took that decision:

- implied: (Why did I act like this?)

(c) explanation, in which $\mathrm{C}$ makes the reason for her decisions explicit:

"the way I chose the material, why I chose that as we were discussing. It must be added that they (the students) wouldn't have been able to do it, so I had to create a route for them (to accomplish the activity), because they were not ready for that; I had to give alternatives for changes."

(d) implicit problematisation, in which $\mathrm{C}$ still problematises her concluding statement, in an implicit way:

"Why do I say that I am behaviourist?"

(e) justification:

"(because) I know that I gave them the content, I gave them the model, I told them what they have to do. We were discussing that..."

The organisation above shows a structure frequently found in the data. That is, when describing the classroom events, organised in spontaneous language, the teachers begin to verbalise a new understanding of that practice. This action of informing makes a kind of confronting possible which involves a problematisation of classroom practice and its relation to the social practices of the school, but it also makes the confronting to be made in relation to a wider context possible. Both actions make it possible for theories on classroom practices to be developed, already informed by scientific concepts, though still seen as technical, superficial information.

Summing up, as discussed in the theoretical section, the actions of describing provided the teachers with the possibility of looking at their classroom actions and by describing them start a problematisation with the explanatory sequence. This led on to rethinking in the light of the theoretical concepts discussed in the course, establishing an initial relationship between theory and practice in the dialogue with a colleague, as pointed out in the theoretical discussion in this study.

As Smyth points out, describing and theorising on our own practice is important, but critical reflection entails more than that. It 
assumes that the teacher questions her representations on teachinglearning, her relation with social practices, the interests they serve, the visions of power that they incorporate. In the interactions analysed, although some questions put by the teacher leading the discussion might have left some space for confronting, the levels proposed by Smyth were not reached. Actually, confronting, as structured by some of the dyads, moved on a bit towards informing. It is important to emphasize that the central focus of teachers is usually on content and that the discussion of the social function of class is new for them. It is shown by Example 2 and also by the fragment below, Example 3, taken from the interaction between $\mathrm{O}$ and $\mathrm{N}$. Here $\mathrm{O}$, by means of questions, cooperates with $\mathrm{N}$ in the problematisation and on evaluation of the students' learning.

Example 3

O15: ... and do you think that you were able to reach your objective in that class?

N15: Well, I don't know if that objective was the ideal one [makes faces], but at least in that class about signs of culture I managed...

O16: And they learned the words related to adjectives

N16: by what they said at the end of the class, at least something they learned.

O17: In general, did the class learn? [moves the hand holding a pen].

N17: They learned, I think they did [nods].

O18: How did you know they'd learned?

N18: Because at the end I asked them to choose a picture, those I'd put on the board, and asked them to ask a question using those situations and the majority, of course I couldn't check the whole class, but some at the end of the class showed me and I saw that the structure of the sentence was correct (smiles at the camera).

As we see, $\mathrm{N}$ organises her turns as an argumentative sequence initiated by two conclusions to answer O's questioning. Thus:

(a) initial conclusion 1:

"Well, I don't know if that objective was the ideal one [B makes faces]." 
(b) initial conclusion 2:

"but at least in that class about signs of culture I managed ..."

(c) arguments for conclusion 2: support from the students' opinion

"by what they said at the end of the class, at least something they learned."

(d) retaking of conclusion 2 :

"They learned, I think they did" [nods].

(e) arguments: description of actions as support

"Because at the end I asked them to choose a picture, those I'd put on the board, and asked them to ask a question using those situations and the majority, of course I couldn't check the whole class, but some at the end of the class showed me and I saw that the structure of the sentence was correct" [smiles at the camera].

The interaction above shows that $O$ provides an initial context for $\mathrm{N}$ to rethink learning: and do you think that you were able to reach your objective in that class? N, based on that questioning, introduces an argumentative sequence, but $\mathrm{O}$ is not able to expand the statement introduced by $\mathrm{N}$, making the action of confronting more difficult. So, there is no discussion about the type of learning which takes place, what social practices are involved, the interests they serve. As the importance of that learning for the students is not problematised, the teacher seems to maintain those representations on teaching-learning already pointed out.

This fragment shows the importance of the role of the guide in the construction of critical reflection in the reflective session, as well as the importance of the level of apropriation by the teachers not only of the scientific concepts of teaching-learning a second language focused on in the course, but also of the concepts of critical reflection by both teachers in the dyad. Although $\mathrm{O}$ asks questions relating to informing and confronting, she is not able to go more deeply into the questions by relying on N's answers, which is in fact a crucial problem, as our objective with this module is the development of multipliers, exactly O's role.

The segments of the interactions already discussed show the teachers' difficulties in appropriating not only the theories related to learning-teaching, but also how to work with content, which made it difficult for the reflection leaders to reach their restructuring proposals. 
As Smyth (1992, p. 278) points out, "when teachers are able to think consciously about the processes that inform their practice with the wider political and cultural-social realities within which it ocurs, then they are able to understand why things work or do not work." In this way they can take decisions regarding the reconstruction of their practice in a specific context.

As we pointed out, the teachers in none of the dyads were totally capable of performing the actions required in a reflective processs, during the classroom work, as discussed in section 2 above. Consequently, their proposals for reconstruction remained at the level of the relations between spontaneous and scientific concepts already pointed out, i.e., in a mechanical and technical way. Let us look at excerpt 4 below to see how $\mathrm{N}$ replies to $\mathrm{O}$ about the possibility of change.

Example 4

O19: And do you think you can change?

N19: Oh, yes, I can. As I said before, I was "very behaviouristic", right? I think that I can change by bringing this context of structures to a real text, right? But I didn't do that. I just put a structure on the board, and they repeated the structure without a real text.

O20: So, all they had to do was talk about the picture?

N20: You see, the picture didn't have a text connected with it. Well, I think that if I bring a text things will become more real, more significant.

O21: True.

N21: Right.

O22: So, you think that ... having a text...

N22: Yes. A text which is meaningful in terms of their real life ...so that they don't have to ask "Why am I learning this?" ... if I'm not going to use it in a real situation [O23: it becomes sort of loose, lost] yes, sort of lost as there was no context of real life in which they might be using that...

O24: So, next time you teach this you'll be using a text ...

N24: For sure...

As an answer to the restructuring question put by $\mathrm{O}, \mathrm{N}$ organises her answer in an explanatory sequence in which she explains what to change, why to change and how to change, which involves confrontation with 
a problematisation of her action, thus offering a base for her proposal for reconstruction. Thus:

(a) initial statement

$\mathrm{N}$ shows her intention to change:

"yes, I can (change)."

(b) problematisation:

$\mathrm{N}$, considering that her statement may be problematic, not totally understandable for her interlocutor, problematises her initial statement:

- implicit: "Why can I change?"

(c) explanation: $\mathrm{N}$ explains why she is going to change and how, making her understanding of her action clear, as a result of confrontation and her decision to change as a result of that:

"Oh, yes, I can. As I said before, I was "very behaviouristic", right? I think that I can change by bringing this context of structures to a real text, right?, but I didn't do that. I just put a structure on the board, and they repeated the structure without a real text.

You see, the picture didn't have a text connected with it. Well, I think that if I bring a text things will become more real, more significant."

(d) conclusion-evaluation: $\mathrm{N}$ goes back to, reformulates and complements what she is going to change and why:

"Yes. A text which is meaningful in terms of their real life ...so that they don't have to ask "Why am I learning this?" ... if I'm not going to use it in a real situation [O23: it becomes sort of loose, lost] yes, sort of lost as there was no context of real life in which they might be using that..."

\section{Final reflections}

The discussions above show on the one hand the importance of the event - reflective session - as a classroom activity in the education of critical teachers in relation to their actions and in relation to teachinglearning in their classrooms. As the description of the sessions shows, there is no doubt that the largest part of the dyads organised their discourses so as to reach the objective proposed by the teacher of the module, although revealing problems already expected in this initial work with this new discursive organization. 
The examples discussed also revealed the importance of providing English teachers with a context conducive to reflective practice. They also showed the need to work, with teachers, how to organize their discourse, so that they can act as an "other" to their peers as well as to themselves. In this way, teachers will have the possibility to learn how to question classroom practices based on scientific teachinglearning concepts, and on concepts of how to create a collaborative set up. This will enable participants to examine their classes critically and to create a space for reflection and new meaning construction.

Also, the discursive organization provided the class teacher with further opportunities to discuss, in classroom, the ways the dyads organized their discourse and the objectives reached. By looking again at their interactions teachers learned the importance of organizing their discourse with specific linguistic-discursive choices to reach the desired aim.

Finally, the data analysis revealed where the problems were. That is, the module teacher was able to see the participant teachers still had difficulty with the tool, as well as with the scientific concepts on teaching-learning focused on during other modules of the course. Thus, working with this analysis also showed the course coordinators and module teachers in which direction to work to try to solve the problems. In other words, it helped us to rethink the course structure in order to solve the problems revealed by data analysis.

\section{References}

AU, K. H. Changes in a teacher's views of interactive comprehension instruction. In: MOLL, L. C. (Ed). Vygotsky and Education. Cambridge: Cambridge University Press, 1990. p. 271-286.

BAKHTIN, M. Os gêneros do discurso. In: BAKHTIN, M. Estética da criação verbal. São Paulo: Martins Fontes, 1952-53. p.277-326.

BRONCKART, J.P. Atividade de linguagem, textos e discursos: Por um interacionismo sócio discursivo. Trad. Anna Rachel Machado. São Paulo: EDUC, 1999. 353p.

CELANI, M.A.A. "You've snatched the carpet from under my feet": courses as contexts for change in in-service teacher education. In: KOIKE, I. (Ed.) Selected Papers from AILA'99 Tokyo. Waseda University Press, 2000. p. 242257. 
COULTER, D. The epic and the novel: Dialogism and teacher education. Educational Researcher, v. 28, n.3, p. 4-13, 1999.

CROWLEY, T. Bakhtin and the history of the language. In: HIRSCHKOP, K; SHEPHERD, D. (Ed.). Bakbtin and Cultural Theory. Manchester: Manchester University Press, 1989. p.68-90.

FULLAN, M.C. Turning systematic thinking on its head. Phi Delta Kappan, February, 1996. p. 420-423.

FREIRE, P. Pedagogy of the opressed. Harmondsworth: Penguin, 1972.

GRIMMET, P.; ERICKSON, G. Reflection on teacher education. New York: Teachers College Press, 1988.

HABERMAS, J. O discurso filosófico da modernidade. Lisboa: Dom Quixote, 1990.

HABERMAS, J. Teoría de la acción comunicativa. Madrid: Taurus, 1981. HOLQUIST, M. Dialogism: Bakhtin and his world. London: Routledge, 1990. LIBERALI, F. Developing argumentative processes for critical reflection. Paper presented in the Fourth Conference on Reflective Teaching, Leuven, Belgium, 1999.

MAGALHÃES, M.C.C. Formation Continue de Professeurs: Séance de Réflexion comme Espace de Négociation entre Professeurs. Cabiers De La Section Des Sciences de l'Éducation, v. 91, p. 191-214, 1999.

MAGALHÃES, M.C.C. Pesquisa em formação de educadores: A pragmática como negociação de sentidos. Cadernos de Lingüistica Aplicada, v. 30, p. 57-70, 1996.

MAGALHÃES, M.C.C. Teacher and researcher dialogical interactions: learning and promoting literacy development. In: ALVAREZ, A.; DEL RIO, P. (Ed.). Education as social construction. Madrid: Infancia y Aprendizaje, 1994. p.199-207.

MAGALHÃES, M.C.C.; CELANI, M.A.A. Continuing education: teachers' collaboration in the construction of meaning in their classroom discourse practices. Comunicação apresentada no congresso Brasil 2000, Unicamp, Campinas, São Paulo, 2000.

PÈREZ-GOMEZ, A. O Pensamento Prático do Professor: a formação do Professor como Profissional Reflexivo. In: NÓVOA, A. (Org.). Os professores e sua formação. Lisboa: Publicações Dom Quixote, 1992. p. 93-114. 
PERRENOUD, P. Formar professores em contextos sociais em mudança. Revista Brasileira de Educação, n. 12. p.5-19. Trad. Denise Barbara Catani. 1999.

SCHNEUWLY, B. Genres et types de discours: considérations psychologiquees et ontogénétiques. In: REUTEUR, Y. (Org.). Les interactions lecture-écriture. Berne: Peter Lang S.A., 1994. p. 155-173.

SCHÖN, D. Formar professores como profissionais reflexivos. In: NÓVOA, A. (Org.). Os professores e sua formação. Lisboa: Publicações Dom Quixote, 1992. p. 77-92.

SCHÖN, D. Educating the Reflective Practicioner. San Francisco: Jossey Bass Publishers, 1987.

SMYTH, J. Teacher's work and the politics of reflection. American Educational Research Journal, v. 29, n. 2, p. 267-300, 1992.

VYGOTSKY, L.S. Pensamento e linguagem. São Paulo: Martins Fontes, 1987.

VYGOTSKY, L.S. In: COLE, M. et al (Org.). Mind in society. Cambridge: Harvard University Press, 1978.

WERTSCH, J.; SMOLKA, A.L.B. Continuando o diálogo: Vygotsky, Bakhtin e Lotman. In: DANIELS, Harry (Org.). Vygotsky em Foco: Pressupostos e Desdobramentos. Campinas, SP: Papirus, 1993. p. 121-150.

ZEICHNER, K.M.; LISTON, D. P. Teaching student teachers to reflect. Harvard Educational Review, v. 57, n. 1, p.23-46, 1987. 